\title{
LABOR'S INTEREST IN RAILROAD REORGANIZATION
}

\author{
A. F. WHITNEY
}

There is no group of our citizenry that is not directly and vitally affected by the problem of railroad reorganization. The railroads now in the hands of the courts have a total capitalization of almost $\$ 6,000,000,000$. The entire national transportation system and, with it, hundreds of thousands of security holders, shippers, and millions of consumers of goods transported by the railroads are affected. When we consider that, in industries other than the railroad industry, there are only about 577 bankruptcy cases ${ }^{1}$ arising under Chapter 10 of the Bankruptcy Act, of which only some 43 insolvent companies have a debt of as much as $\$ 1,000,000$ each, and the total assets in all of the cases aggregate only about $\$ 385,000,000$, as compared with the book assets of 15 or 20 times as much in the case of railroads in receivership and under Section 77 of the Bankruptcy Act, it can be seen that railroad reorganization presents a problem that requires special consideration and treatment. The widespread effect of the problem of railroads in receivership may best be described by quoting from the report on S. 1869, the Railroad Reorganization Bill, submitted by Senator Burton $\mathrm{K}$. Wheeler, Chairman of the Senate Committee on Interstate Commerce:

Railroad corporations as defined in this section are affected with a national public interest in that among other things (i) they are engaged in a common carrier service of transportation of persons and property in interstate commerce, and are important purchasers of materials and equipment whose manufacture, sale, and transportation influence a substantial volume of interstate commerce; (ii) their securities are widely marketed and distributed by means of the mails and instrumentalities of interstate commerce and are sold to a large number of investors in different states; (iii) their activities extendiag over many States are not susceptible of effective regulation by any State and make difficult, if not impossible, effective State regulation thercof; (iv) they are essential instruments of the national defense; (v) transactions in, and market prices of their securities matcrially affect the national credit, the Federal taxing power, the national banking system, the Federal Reserve System, and the maintenance of fair and honest markets in transactions in and affecting interstate commerce; and involve the use of credit of, and dircctly affect the finaneing of trade, industry, and transportation in interstate commerce and influence the volume

\footnotetext{
- President of the Brotherhood of Railroad Trainmen since 1928; Vice-President, 1907-1928. Chairman, Railway Labor Executives Association, 1932-1934; delegate to Inter-American Conference for the Maintenance of Peace, Buenos Aires, December, 1936. Contributor to periodicals.

${ }^{1}$ To June 30,1939 , latest date for which statisties are available.
} 
of interstate commerce. That national public interest is materially and adversely affected by the insolvency or inability of such railroad corporations to meet their maturing obligations and by their need for financial reorganization. Such insolvency, inability, and need reduce the volume of employment by such railroads and the compensation paid their employees, their purchases of material and equipment needed in interstate commerce and the adequacy of maintenance of their properties used in interstate commerce, with resulting impairment of their service and the public safety in interstate commerce, and impair the transactions in and markets for their securities, and jeopardize the national defense. $\mathrm{Na}$ tional emergencies which produce widespread unemployment and the dislocation of trade, transportation, and industry, and which burden interstate commerce, affect the general welfare and impair the national defense are precipitated, intensified, and prolonged by such insolvency, inability, and need. Such insolvency, inability, and need result from unsound financial structures and unsound financial reorganizations which have been persistent.1*

Although all groups of citizens are affected by railroad reorganizations, railroad labor, of course, has a very direct interest in the subject. The financial mismanagement and plundering that precede railroad receivership, as well as the financial exploitation that usually accompanies railroads in receivership, not only cause railroad labor to suffer directly, but also afford the means by which railroad labor is blamed for the errors of others. One-half century of experience in the railroad industry, as an employee and employee representative, has convinced nie that railroad labor's fight foi economic justice must be directed mainly against railroad bankers and financiers, rather than against the practical operating managements.

The history of American railroad reorganization conclusively establishes the fact that unsound reorganizations seriously interfere with the functioning of railroads as transportation agencies. Management, forced to seek funds to meet unjustified fixed charges, desperately attempts to procure money by saving through under-maintenance and reduction in labor costs, both to the harm of employees and the public. Unsound financial reorganizations impose upon operating management many distracting burdens and problems, with the result that the operating managers take their minds off the transportation business and turn to considering Wall Street financial problems. The court in charge of the Seaboard Air Line Railway receivership, taking cognizance of the road's financial problems which had so burdened the receivers appointed by the court, commented as follows:

The time the receivers and their counsel are required to give to financial problems which are constantly arising in connection with the operation of this important railway system has amazed me from the beginning. I will give instances of that-the temporary refunding plan, which was adopted in February r932, required a great deal of their time both before and after that plan was approved by the court. The refunding plan, adopted in March I935 must have taken nearly 6 months of the time of the receivers and their counsel, free to give their time, energy, and talent to the operation of a transportation system were engaged in solving financial problems rather than transportation problems. It docs not seem to me that situation or anything like it should exist after a reorganization

2n SEN. R.P. No. 454, 76th Cong., ist Sess. (1939) 2. 
but that, on the contrary, the executives ought to be free to give their time, energy and talent to the operation of a transportation system as such, and not be constantly worried over financial problems. They ought also to be the masters of the situation and not under the control of any group or groups. I say that without any intention to reflect on any group or groups, but it seems to me that is essentially a transportation system and that it must be operated as such.?

It is needless to point out that unsound reorganizations do not even benefit the security holders for whom financially improvident commitments are often made. Unrealistic railroad reorganizations which create securities that will earn nothing, create securities in name only. No dividends have been paid on the common stock of the Seaboard Air Line Railway Company since it was created in 1900 and, although the common stock has survived or has been reissued in various reorganizations of that company, the distribution and redistribution of these picces of paper have been futile except to delude the recipients of the securities. In the case of the St. Paul Railway, no dividends have been paid on the stock for more than two decades, and in the Chicago and Eastern Illinois, no dividends have been paid on the common stock for more than a quarter of a century. In the case of the Western Pacific, no dividends have been paid for years. These railroads operate in four different sections of the country and everyone of them is a repeater in the matter of receivership and reorganization. Approximately 4,500,000 worthless shares of stock were distributed to the public in the reorganizations of these four companies alone.

Dividends declared on such valueless stock are false dividends and necessitate false bookkeeping, leading in turn to more financing through the issuance of unsound stock. When it discovered that the income of the St. Paul Railway had been overstated for the year 1910, in the amount of $\$ 5,000,000$, the Interstate Commerce Commission, in a report in $\mathrm{Igr}_{4}$, stated:

... a carrier's ... statements of net revenue often reflected nothing more than the particular showing desired by its executive. These reports were often used for speculative purposes, and the stockholder and the general public were left without any assurance as to whether the dividends declared were paid from income, surplus, or out of capital. . . . These departures from what were the actual facts are sufficiently serious to merit the strongest condemnation. ${ }^{3}$

Innocent purchasers were induced to buy such valueless securities in reliance upon the certificate issued by a government agency, the Interstate Commerce Commission, and they had a right to believe that the creation and distribution of this stock was compatible with the public interest. It has well been said that such valueless securities "are mere tokens for stock market speculation and enable shrewd holders to unload on the unsuspecting public." Such unsound reorganizations of

\footnotetext{
'U. S. Dist. Cr. hearings, Norfolk, Va., Jan. 17, 1937, pp. 10-11, quoted in Hearing before the Special Sutcommittee on Bankruptcy and Reorganization of the House Committec on the Judiciary, 76th Cong., 1st Sess. (1939) Pt. 2, p. 169.

-St. Paul and Puget Sound Accounts, 29 I. C. C. 508, 510,512 (1914).
} 
railroads offer golden opportunities to insiders and shrewd speculators to unload on the unwary public. In a report submitted to Senator Daniel O. Hastings in January, 1933, the legislative committee of the Interstate Commerce Commission had the following to say:

It should also be stated that railroad receiverships and reorganizations have frequently furnished an opportunity for speculative profits by those having inside information. Foreknowledge that the appointment of receivers will be sought may furnish an opportunity for such profit through short-selling of the railroad's stock. During the receivership, also, securities of the old company sell at very low prices and large expenditures may be made by the receivers in bringing the property to first-class physical condition. After receivership, such maintenance expense may be curtailed, thus improving the net earnings of the property, and giving insiders who have acquired old securities at low prices an opportunity to unload at a profit the new securities received in exchange. Railroad statistics and stock market quotations furnish circumstancial evidence that this sort of thing has frequently happened. 4

Not only are valueless stock securities that are issued in railroad reorganizations used as a means of mulcting the public through stock market operations, but frequently such valueless stock certificates are used by persons interested in controlling a particular railroad. Commissioner Joseph B. Eastman, in testifying before the House Judiciary Committee in 1935, stated the following:

Some stockholders may be as much interested in their holdings from the standpoint of control as from the standpoint of investment, and perhaps more interested. This is particularly true where the stockholder is a railroad or a railroad holding company. Stock interests are often obtained in such cases, not for the sake of any direct return on the investment, but for the sake of the less direct advantages which are obtained through control of the property.s

Commissioner Eastman then gave several examples of roads so controlled, such as the Missouri Pacific, the Chicago \& Eastern Illinois, the Wabash, and the Rock Island, and continued:

I am not suggesting, of course, that such stock interests are not entitled to every reasonable and legitimate protection. I do call your attention to the fact, however, that they are not stockholders of the widow and orphan class but have a reason for retaining their holdings, namely, control, which goes beyond any direct return on the investment. The retention of this control might well be to their advantage, even if not a dollar in dividends upon the stock could ever be anticipated."

Accumulation of securities for purposes of control may have very adverse effects upon the railroad industry. It places control in the hands of groups whose primary. profit interests may be other than the proper conduct of the railroad as a transporta-

- Quoted from 2 letter by Commissioner J. B. Eastman, reprinted in full in Hearing before the SubCommittee on Bankrupicy and Reorganization of the House Committee on the Judiciary on S. 1869, 76th Cong., Ist Sess. (1939) Pt. I, pp. 144, 148.

- Hearing before the House Committee on the Judiciary on H.R.6249, 74th Cong., Ist Sess. (1935) 282.

- Id. at 283 . 
tion agency. Mulcting operations, by holding companies and others, through increases of salaries and by purchases of supplies and equipment, result in large profits to the holders of such securities, to the serious detriment of the railroad whose securities are so held. Control through stock ownership may also be used by one railroad to control another railroad, to the profit of the former and to the detriment of the latter.

Anyone familiar with the railroad industry knows that it is characterized by "feast and famine." There are railroad corporations which are among the richest in the United States; there are other railroads which are in serious financial difficulties. This bad situation is augmented by the plundering of a few railroads not only by financiers and manipulators, but by the richer railroads "milking" the poorer railroads As an illustration, stockholders and bondholders of the St. Louis Southwestern Rail. road have brought a proceeding before the Interstate Commerce Commission to in. vestigate their charges that the Southern Pacific has been using its stock control of the St. Louis Southwestern in the interests of the Southern Pacific and to the damage of the St. Louis Southwestern. The purchasing, at comparatively low prices, of a controlling block of railway stock, valueless except for purposes of control, results in the sale of the control of railroads just as though such control were any commodity. Such sale of control not only results in disaster to the controlled railroads, but frequently induces railroads to go from one step to another until the controlling railroad likewise is engulfed in the financial exploitation, with resultant heavy financial losses.

The sale of valueless securities, resulting from unsound railroad reorganizations, frequently forces a subsequent receivership of the reorganized railroad. Examples of this are too well known to need citation. Railroads are constantly burdening their financial structures with additional capital expenditures. This is well illustrated by the testimony before the House Judiciary Committee on June 14, 1939, by Mr. Marcus L. Bell, General Counsel, Chicago, Rock Island and Pacific Railway Company, when he said:

Let us say that the station building at Podunk or Pine Bluff, let us say is worn with the travel of the years, and it finally falls over. It was a wooden building, and the chamber of commerce goes up to the division superintendent and says, "Look here, brother, we are in a better town than Redfield, and we are pretty near as big as Memphis, and we have to have a brick building." All right, the old station cost $\$ 3,000$, and the new station will cost $\$ 40,000$. So, $\$ 3,000$ is wiped of and charged to maintenance, or retirements, and $\$ 37,000$ is charged to capital, and it works the same way in every department of the railroad, bridges, stations, and rails, and the total of that on the Rock Island is $\$ 3,000,000$ on that for each year that we have to put into property, whether we do anything more than just keeping it in running order or not. We have it today and every other railroad has it today. Our capital grows $\$ 3,000,000$ every year. ${ }^{7}$

A railroad cannot meet its financing requirements by the sale of junior securitics when the junior securities already issued are of poor quality or valueless. The issuance

Thearing, supra note 4, at 443. 
of additional worthless paper simply will not bring in the money from investors. Accordingly, a road confronted with such a condition must meet its financing requirements by selling interest-bearing senior securities, thereby increasing its debts and fixed charges, which, of course, will ultimately result in another insolvency. It is by such devices that railroad properties become loaded down with bonds which have been the curse of the financial policies obtaining in the railroad industry. The important consideration here is that even though a reorganized railroad starts off without excessive fixed charges, if it has too large a capitalization for the earning power of the road, eventually it will go into receivership through the necessity of issuing interest-bearing bonds or debts, because the process of financing through the issuance of junior securities is no longer a practical possibilicy.

It is important to note also that earnings alone, of a railroad, do not determine its credit. Of course, a railroad that has no earnings will have difficulty in selling securities of any type. But, whatever may be the earnings of a railroad, if its financial structure is such as to prevent financing by the sale of junior securities, thereby forcing it to finance by the sale of fixed interest-bearing, debt-creating securities, its earnings will eventually become too small for the size of its capitalizacion and the interest on its bonds or preferred stock dividends will ahsorb every penny that the railroad is able to earn. Thus, both the earnings and the financial structure of a railroad have an important bearing on its credit standing and its financial soundness.

The opportunity to meet, in an intelligent manner, the problems herein discussed, arises at the time of the reorganization. It simply does not make sense to take into consideration what a railroad cost some years ago or how much money had been invested in the railroad, in fixing the capitalization of a reorganized railroad. The value of a railroad is determined by its present and future earning power. The Railroad Reorganization Bill, S. 1869, which has already been passed by the Senate and is now tied up in the House Judiciary Committee, proposes to lay down as a rebuttable presumption the theory that the earning power of a railroad should determine its capitalization and such earning power is arrived at by establishing the rebuttable presumption that the future earning power will be equal to the average earning power of the road over the past twelve years. If railroads in the past had been reorganized on such a sound basis, they would not be in the constant process of reorganization, as their capitalization would be based on a realistic foundation which would result in a sound financial structure and enable the railroads to do the necessary financing in the course of their business and at the same time maintain solvency. The financial interests are bitterly opposed to the doctrine of establishing capitalization on the basis of the rebuttable presumption as to earnings, but for the most part they are the group who stand to profit from unsound railroad reorganizations and consolidations. In a communication dated July 8, I939, addressed to the Committee on Interstate Commerce of the United States Senate, Commissioner Joseph B. Eastman said: 
If experience is any criterion, the chief beneficiary for some years would be the bankers and lawyers in charge of negotiation. ${ }^{8}$

This statement was made with reference to a proposed plan for encouraging railroad consolidations. The Brotherhood of Railroad Trainmen has long opposed the policy of railroad consolidations and improvident railroad reorganizations, because we know that such financial manipulations never propose to improve service to shippers or to reduce rates, or to improve working standards of the employees. On the contrary, they serve only the interests of bankers and lawyers who reap huge fees from such transactions. These interests do not want the government to lay down any specific standards for the consummation of such transactions. Hence, they vigorously oppose the rebuttable presumption provided for in S. 1869 , previously mentioned, which would create a realistic capitalization for reorganized railroads, such capitalization being based upon the probable future earning power of the road. This opposition was well illustrated by Mr. Bell, above quoted. In 1939, he testified against the provisions relating to the rebuttable presumption in S. 1869 . In appearing before the House Judiciary Committee in 1935 , he said:

I object to this act having anything in it about valuation . . . just leave it out . . . the valuation should come out of this thing. ...

The wisest thing that was ever said to the Interstate Commerce Commission-and I have no doubt that men are within the sound of my voice who heard it said-was said by Commissioner Prouty one day 15 or 20 years ago. We were talking to the Commission -it was after he left the Commission; he was in charge of the Bureau of Valuation; and I hope these gentlemen will correct me if I am wrong-he stood up and said to the Commission:

"Go ahead and make your values but do not tell anybody how you do it, because if you lay down a rule, somebody is going to attack the rule. If you make your values let them attack the values, but keep your rule to yourself." ... mission."

"What you need is a provision for issuing securities, without limitaton on the Com-

In an article of this length, the subject of railroad reorganizations could not be dealt with completely. Enough has been said, however, to indicate that there are grave social and economic problems involved in railroad reorganizations. Furthermore, it is clear that receivership and reorganization in the railroad industry is of such vital importance and requires such technical training and skill, as to make it imperative that a special railroad reorganization court be established. Such a court would be composed of judges and assistants who are experts in this field and who would be able to cope with the talent of the railroad reorganization bar. Under present conditions, our courts not only are unfamiliar with the problems of railroad reorganization, nor do they have assistants who are familiar with this subject, but they are required to take railroad reorganization cases along with assignments of

- Quoted in Hearing, supra note 4, Pt. 2, p. 186.

'Hearings before the House Committee on the Judiciary on H. R. 6249, 74th Cong., 1st Sess. (1935) $271,278,279$. 
many other cases, a fact which gives then neither the time nor the opportunity to give consideration to the problems that arise in this complex and vitally important problem of railroad reorganization.

As can be seen from the foregoing, railroads are brought to financial difficulties because of the manipulations and exploitations by financial interests and stock market operators. When railroads are reorganized on an unsound basis, railroad manage. ments simply cannot operate them with fairness to the traveling and shipping public and with justice to their employees. Driven to desperation by unreasonable financial requirements, railroad operating managements resort to under-maintenance and reduction in the number and quality of transportation services to the public. They undertake to slash their labor costs, and, when organized railroad labor meets the challenge in an effort to protect the human assets of the industry, the giant railroad propaganda machine goes into action through press, radio, and every avenue of publicity, in an effort to make the public believe that the railroad workers, rather than improvident and extravagant financial manipulation, is the cause of the railroads' difficulties. Of course, railroad labor has an impressive and effective reply to such propaganda, because railroad workers are now producing more revenue per wage dollar than ever before in history, so whatever may be wrong with the railrogd industry, it cannot be laid at the door of the railway workers, whose ever-rising productivity has reduced their number from approximately 2,000,000 to approximately $\mathrm{r}, 000,000$, within the last two decades. Labor may also answer the propaganda attacks upon it, by reminding the country that, as a result of the Senate investigation of railroad financial policies, Senator Burton K. Wheeler, Chairman of the Senate Railroad Investigating Committee, declared that the railroads are wasting a million dollars a day, or $\$ 365,000,000$ annually. Much of this waste arises out of malpractices discussed in this article.

Finally, a word should be said about the problem of competition which the railroads now have to meet. It is true that the railroads once had a virtual monopoly in the transportation field and, for one who has enjoyed the complacency of such monopoly, it is frequently difficult to bestir oneself to meet competition as it arises to threaten the monopoly advantage so long enjoyed. Railroad managements are properly criticized for having been lethargic during the growth of competition from trucks and other forms of transportation. This is an age of mass production and in virtually all industries, except the railroad industry, the small producer is being ingulfed by the mass producer. But, the railroad industry with its vast mass-carrying capacity, as compared with its competitors, complains greatly because of the new forms of competition. The railroads have demonstrated their ability to meet and defeat competition when they set out in earnest to do so.

When the passenger business first began to leave the railroads, instead of offering faster service and cheaper transportation, the railroads continued to pull off passenger trains, claiming that the passenger business had gone to the private car owner and would never return to the rails. 
But the chief difficulty in the railroad industry was pointed out by the judge who was "amażed" at the amount of time railroad managements are required to spend on financial matters which divert their talents and attention from the problems of efficient transportation in this competitive age. Sound financial reorganizations and sound financial policies which would permit railroad managements to devote more of their time and more of the industry's earnings to modern transportation requirements and equipment, instead of so great a devotion to false securities and improvident financial policies, would result in far greater benefits to the shippers and consuming public. It would enable the railroads, so indispensable to the year-around transportation needs of our nation, to adopt lighter and more flexible equipment, instead of following the banker policy of getting the maximum from labor through the use of costly, heavy and inflexible equipment. More speedy and flexible service would enable the railroads to compete more effectively and to restore business volumes and employment in the railroad industry. Present financial policies handicap the railroads in meeting competition, and this in turn aggravates the financial difficulties of the railroad industry. 